\title{
An Investigation into Teacher Written Feedback on English Writing
}

\author{
Chunxia Zhang \\ Foreign Languages School, Jingchu University of Technology, Jingmen, Hubei, 448000, \\ 568273258@qq.com
}

Keywords: English Writing; Teacher written feedback; Students' Attitudes; Direct Feedback; Indirect Feedback

\begin{abstract}
The teacher written feedback helps to improve the students' writing ability. In the current college English writing teaching, it's necessary to introduce teacher written feedback on English Writing. The paper investigates and analyzes different types of teacher written feedbacks and students' attitudes towards the different feedbacks. Finally, the paper has some implications for the teacher written feedback on the teaching of writing.
\end{abstract}

\section{Introduction}

Teacher written feedback to students' writing has always been an important part of writing. It also plays an important role in guiding students to write, and ensuring the teaching effect. Feedback in writing refers to "the readers offer input to the author, which is intended to provide information for the author to modify his article" (Keh, 1990) [1]. This information includes form-focused feedback and content/organization-focused feedback, the former refers to offering feedback about the errors existing in grammar, vocabulary and writing pattern, so form-focused feedback is also called the error correcting feedback or grammar feedback. Form-focused feedback is mainly reflected in the direct feedback and indirect. The direct feedback is that the teacher not only points out error but also directly offers correct answers, and indirect feedback refers that the teachers do not provide the correct answer but indicate errors or problems through other means, and then let students correct by themselves. Content feedback is to make a comment on the writing content, organization, cohesion and coherence, etc. In addition, the teachers' commentary and score grading are also an important channel of information feedback.

Teacher written feedback is one of the main research topics in the field of foreign language writing teaching, and has attracted much attention in the past 30 years. Extensive researches about the teacher written feedback have been carried out at home and abroad. Whether teachers' written-feedback should focus on the form of language or the ideological content has been argued by many researchers, and which type of feedback has better effect and can thus improve students' writing ability has always been the key point. (Ashwell, 2000) [2]. Whether direct or indirect feedback is beneficial to improve the accuracy of their language expression is still under debate. Some researches show that indirect correction is helpful to the second language learners. (Ferris \& Helt 2000; Ferris 2003) [3,4], this is mainly because that indirect correction can urge students focus on language form, mobilize and guide them participate in the problem solving. However, some researches show that direct correction is better because it is more beneficial for the students' writing proficiency. (Sheen 2007; Bitchener 2008; Bitchener\& Knoch 2008)[5, 6, 7], because this kind of correction can help students correct their errors, especially for the poor learners. There are few empirical studies showing that written feedbacks play an important role in improving learners' writing proficiency. The results of these studies show that praise and criticism have no point in improving students' writing performances, but they will affect the learners' attitude towards writing. The same is true with the situation in China. Zhou Yishu (2013) [8] believes that teacher feedback has a significant role in enhancing students' awareness of writing structure, and most students prefer that the teacher adopts flexibly different types of feedback so as to ensure the positive effects of each type of feedback. Li Jing's [9] case study reveals that teacher error and non-error feedback do improve language accuracy in EFL students' writings, and the latter could even attract students' attention to the deep aspects of their writings, thus improving the overall effects of texts. 
The above studies show that the teacher written feedback does play an important role in improving the students' writing, but in the EFL context, what kind of written feedback form is suitable for non-English major college students? It is the question to be solved in this paper, which intends to discuss the teacher written feedback in the terms of form and types, and to find out the suitable ones for non-English majors.

\section{Research Method}

Research Questions. 1. What kind of written feedbacks will be offered by English teachers? 2. Which kind of written feedbacks will be accepted by the students and what are their attitudes towards these feedbacks?

The Subjects of Study. 8 college English teachers from a local undergraduate colleges and universities in Hubei province participate in the study, including one male teacher and seven female teachers who are between 27 and 45 years old. Subjects are 80 sophomores majoring in art, 62 girls and 18 boys included.

Research Methods and Means. This study includes two methods. One is the text analysis. Subjects are asked to complete a composition within 30 minutes, the requirements of the composition are from College English Test Band 4 (CET-4) writing. And assignments are asked to be handed in immediately they finished. Based on the global scoring, the teachers make comprehensive assessment from the form and the language. The global scoring takes the contents and the overall impression of the language expression into consideration. Thus the teachers give reward scores to the better compositions. Each teacher assesses ten compositions, and marks each of them by 2 points, 5 points, 8 points, 11 points and 14 points. And for the written feedback, it depends on the teachers' own feedback habits.

As for the questionnaire, the students are required to answer the following open questions:

1. What kind of feedback do you prefer, form-focused feedback or content-focused feedback? And please give your reasons.

2. As for the form of feedback, do you like direct feedback or indirect feedback? And why?

3. What kind of comments do you like? (praise, criticism, encouragement, advice). In the questionnaire, the author explains the definition of the form-focused feedback, content-focused feedback, direct feedback and indirect feedback in detail.

\section{The Results and Analysis}

Overall Written Feedback. The results show that eight teachers give comprehensive feedbacks, and the most forms they use are score marking and error correction. 80 essays are given different scores and a greater number of error corrections. But for comment feedback, only four teachers give comments, and the other four teachers do not have any comments on these marked compositions.

The Types of Written Feedback. According to the statistical results from the texts, the 8 teacher written feedbacks are mostly based on error correction, with 601 corrections in total. It is focused-form feedback. The teacher is mainly aimed at correcting students' errors exiting in grammar, vocabulary, writing norms and other aspects to provide feedbacks. These kinds of feedbacks are up to 458. While teachers' comment feedbacks for students in the writing of the content, organization, cohesion and coherence are less than the focused-form feedback, only 142. Thus, when correcting student's composition, the teacher mainly focuses on the correctness and accuracy in the form of language, and mainly concentrates on the word spellings and grammatical errors without enough concern for cohesion and coherence of the content .That is to say, for written-feedbacks of composition, the teacher is more concerned about the characteristics of the surface of the composition, and few sufficient feedbacks are given on textual aspect of the article. On the other hand, teachers pay more attention to the students formed errors, and there are 264 direct feedbacks and 194 indirect feedbacks. This shows that teachers are more inclined to direct feedback in focused-form feedback. The result is consistent with the current situation of writing teaching for non-English majors. 
The current purpose of college English writing teaching is to make the students pass the College English Test. In the teaching, teachers usually focused on the form of the writing, seldom pay much attention to the students' critical thinking, so students are often required to be in strict accordance with the requirements of the test, that is, word spellings and grammatical aspects must be required to be correct. It requires both teachers and students to pay great attention to the article form rather than the content. The actual study situation of non English majors is that they are poor at grammar, and there are a lot of grammatical errors and even the word spelling errors when writing each time. This can be proved by the fact that more direct feedback are given compared wit the indirect feedback. What's more, the teachers' indirect feedback is not able to attract students' attention, even if the students have noticed that, but they don't know how to correct them. Research of (Fathman \& Whalley, 1990) [10] Shows that the error correction, especially the indirect syntax error correction, can significantly improve the accuracy of the grammar. The comments about the content can promote learners to make greater progress in the expression of ideas. Kepner's (1991) [11] research also confirms that the comments related to the contents acts a positive role in improving the smooth flow of composition ideas. Therefore, in college English writing teaching, the focus of teachers' feedback should be placed on the content feedback, and for the focused-form feedback, indirect feedback had better been used.

Comments Feedback by the Teachers. From the analysis, there are 23 comments feedbacks given by the teachers in total. These comments include evaluation of form and content, including five praises, no criticism, four encouragements, 6 advices and 6 mixed comments, which show that when the teacher assesses the students' compositions, they usually give praise, encouragement and advice. The results of Hyland's \& Hyland's study (2001)[12] shows that praise and criticism to the thesis revision don't have lots of change, but they will affect the learners' attitude towards writing. Praise can stimulate learners' writing passion, reduce the anxiety of the students who have low capacity in writing, enhance writing skills and strong sense of accomplishment; criticism or positive reviews will discourage the learner's self-confidence, and dampen their enthusiasm for writing. The advice comments are well accepted because they clearly convey the information to the learners on how to improve the writing. Therefore, teachers should give more encouragement and advice in writing.

Students' Attitudes towards Teacher Written Feedback. 80 students in total are interviewed, and questionnaires are all handed in. Through the analysis of the questionnaire, the following conclusions are drawn:

1. As for the form-focused and content-focused feedback, the answers given by the students are not significantly different. $46 \%$ of the students want teachers to give form-focused feedback, because they think that the form of the composition is more important. The rest of the $54 \%$ of the students prefer content-focused feedback, and they think the content is more important.

2. Among the students choosing the focused-form feedback, $78 \%$ of the students like direct feedback, because they feel it is more straightforward and more convenient; for the other $22 \%$ of students, they think that indirect feedback can make them correct their grammar mistakes by themselves, which can deepen the impression and avoid the same mistake in the future.

3. For comments, $49 \%$ of the students like praise and encouraged comments, and $51 \%$ of the students like the advice given by the teacher. No students like the criticized comments, because they feel praise and encouragement can inspire their confidence and make them interested in writing. But the advice comments have the role of guidance. If the teachers just give the assessment of "good" or "bad" without any specific evaluation contents, students are often at a loss and they do not know exactly what are merits and demerits of their writing, and they don't know how to improve the writing ability, so that students do not have any writing skills improvement.

\section{The Suggestions}

Prompt Feedback Is a Must. Each time the students hand in their writings, teachers should spare no effort to assess them, give feedback. Otherwise, the students may not know how to evaluate their own performance. Different types of feedbacks should be provided, for example, peer evaluation, 
on-line evaluation and so on, so the teachers can reduce the limitations of each type.

Appropriate Feedback Are more Popular. In College English composition teaching, teachers should pay more attention to the feedback of the content. In the form of writing, it should be more indirect feedback. In the evaluation of the composition of the form, indirect feedback should be more used. Teachers' comments should be full of praise, and the advice for the students should be specific and detailed, so as to improve the English writing ability of non English majors.

\section{Conclusion}

When giving the written-feedback on non-English Majors' English compositions, the teachers are more focused on the form of feedback, especially the indirect feedback other than the indirect one. Students prefer teachers to give direct feedback in their form errors. For teachers' comments, students are more likely to be praised and encouraged, and more students want to receive teachers' advice on how to improve their writings. The results can give English teachers some suggestions on how to give feedback to students.

\section{References}

[1] Keh, C. L, Feedback in the writing process, A Model and Methods for Implementation, J. ELT Journal. 44 (1990) 294- 394.

[2] Ashwell T, Patterns of teacher response to student writing in a multiple-draft composition classroom: Is content feedback followed by form feedback the best method? J. Journal of Second Language Writing, 9 (2000) 227- 257.

[3] Ferris D R, Helt M, Was Truscott Right? New Evidence on the Effects of Error Correction in L2 Writing Classes, R. Vancouver: The AAAL Conference, 2000.

[4] Ferris D R, Response to Student Writing: Implications for Second Language Students, Mahwah, NJ: Lawrence Erlbaum Associates, 2003.

[5] Sheen Y, The effect of focused written corrective feedback and language aptitude on ESL learners' acquisition of articles, J. TESOL Quarterly, 41 (2007) 255-283.

[6] Bitchener J, Evidence in support of written corrective feedback, J. Journal of Second Language Writing, 17 (2008) 102-118.

[7] U, The value of written corrective feedback for migrant and international students, J. Language Teaching Research, 12 (2008) 409-431.

[8] Yishu Zhou, a Comparative study of different feedbacks in college English writing, J. Fireign Language World. 156(2013) 87-96. (In Chinese)

[9] Jing Li, A case study into teacher written corrective feedback in English writing, J. Fireign Language World. 155(2013) 87-96. (In Chinese)

[10]Fathman, A., E. Whalley, Teacher response to student writing: Focus on form versus content , in Barbara Krol (ed). Second Language Writing: Research Insights for the Classroom. Cambridge: Cambridge University Press, 1990, pp178- 190.

[11]Kepner, C, An experiment in the relationship of types of written feedback to the development of second language writing skills, J. Modern Language Journal, 75(1991) 305- 313.

[12]Hyland, F. , K. Hyland, Sugaring the pill Praise and criticism in written feedback, J. Journal of Second Language Writing, 10 (2001) 185-212. 